\title{
EMPIRICAL ANALYSIS FOR SUCCESS FACTORS IN UBIQUITOUS SUPPLY CHAIN MANAGEMENT IN THE CASE OF UK COMPANIES
}

\author{
ChangsuKim, Yeungnam University, c.kim@yumail.ac.kr \\ Jongheon Kim, Auburn University Montgomery,jkim23@aum.edu
}

\begin{abstract}
This study examines affecting factors on a successful implementation of the ubiquitous supply chain management system (USCMS) perceived by industry managers from UK companies. Upon the thorough review of existing literature on both ubiquitous computing and supply management systems, the current study classified two construct groups for those success factors and employed principle component factor analysis technique and identifies thirteen unique and crucial factors relating to perceived benefits of the USCMS. A managerial success factor construct includes seven relevant factors and a technical factor construct has six success factors. This finding expects to lead a systematic causal model to realize the benefits of USCM implementation based upon these factors suggested.
\end{abstract}

Keywords: Supply Chain Management System, Ubiquitous computing, RFID, Factor Analysis

\section{INTRODUCTION}

Today supply chain management is the crucial topic in business and the well-managed supply chain becomes competitive advantages of many companies. The lack of accurate inventory information in the supply chain management can bring the shortage or surplus of items resulting in sales loss of companies. For example, according to Corsten and Gruen's (2003) study, in the 'out of stock' case, the potential sales loss reaches $3.4 \%$ for retailers and 2.6 for suppliers. In order to solve these problems, the ideal supply chain management is targeting on integrating the flow of information, materials, and services flow through the entire supply channels and then sharing the real-time information among suppliers (Caputo et al., 2004; Hsieh \& Lin, 2004, Trappey et al., 2004; Wu et al., 2004).

From the operations perspectives, resource planning and inventory control systems are highly related to supply chain management, because the ultimate goal of 'resource planning and inventory control system' is to pursue minimum inventory necessary in terms of lean production or Just-in-Time (JIT) production philosophy (Andriolo et al., 2016). To achieve this goal, accurately storing and tracking information of each item are an inevitable part. Traditionally, those works have been done through manual entry or bar code systems that have limited capabilities in certain conditions (Hou \& Hoang, 2006).

Since RFID, an automatic identification method storing and capturing data, was introduced in the supply chain to overcome the limitations of traditional approaches and revolutionize supply chain management, RFID has been one of the fast growing topics in the supply chain (Spekman \& Sweeney, 2006). It is considered one of the most successful adoptions of ubiquitous computing has been applied in the supply chain field (Rodriguez-Escobar \& Gonzalez-Benito, 2015; Schapranow et al., 2012). A supply chain means the whole process from an organization's suppliers to its customers (Rai \& Seth, 2006). Recently, ubiquitous computing technologies such as sensors, radio frequency identification (RFID), mobile devices, personal digital assistant (PDA) and global positioning system are likely to affect all facets of the supply chain management to reduce inventory and distribution costs as well as to improve supplier and customer satisfaction (Findley \& Srikanth, 2005; Lopez et al. 2012). USCM carries out a range of activities such as the planning, control, and management of the supply chain based on ubiquitous computing technology. Thus, it is not surprising that more enterprises are adopting USCM.

In addition to the extension of industry applications, the economic impact of a ubiquitous computing technology is rapidly increasing. For instance, the growth of the overall RFID global market of RFID is expected to reach from $\$ 965$ million in 2002 to $\$ 4.6$ billion by 2007 with the annual rate of $45 \%$ (Ward 2004; Wicks, Visich \& Li, 2006). The sales of RFID technology in the supply chain applications will show 38\% growth rate from \$89million in 2002 to $\$ 448.4$ million by 2007 (Hickey, 2004). 


\section{Issues in Information Systems \\ Volume 17, Issue I, pp. 1-13, 2016}

One of the typical examples is Wal-Mart case (Niederman \& Mathieu, 2011) utilizing RFID as a part of USCMs. Despite the huge cost and possible risks of RFID implementation, the reason why companies such as Wal-Mart, the largest retailer in the world, try to adopt RFID in their supply chains is simply due to the benefits the RFID technology provides. Relating to resource planning and control systems, one of many advantages of RFID technology in the supply chain will be accurate resource planning and control low inventory levels which attract interests and attentions of operators in resource planning and control systems fields. Therefore, the purpose of this paper is to provide information about the benefits of the RFID technology in the supply chain to companies or practitioners which consider RFID implementation.

However, despite its growing adoption, research on USCM has been scant. Little attention has been paid to the key impact factors and USCM adoption benefits that an organization should consider when adopting USCM. This research aims to investigate the relationship between impact factors and USCM adoption benefits. It appears that examining the factors affecting the adoption of USCM and its relationship with USCM adoption benefits, is an important challenge to provide a useful academic foundation and practical information.

In the following section, this paper draws lessons from recent studies on USCM. Section 3 addresses research procedure and methods. Section 4 describes an empirical analysis and result. Section 5 will discuss as to what the findings of statistics imply and finally, conclusions will follow in section 6.

\section{THEORETICAL BACKGROUND}

Supply Chain Management (SCM) is an interorganizational process to minimize the cost in the supply chain, to increase the value of the supply chain, and to remove wasteful business practices (Fish \& Forrest, 2006; Moberg et al., 2004). To date, supply chain management is a digitally enabled inter-enterprise process activity that focuses on improvement and innovation of end-to-end process between enterprises and their customers and suppliers (Barua et al., 2004; Rajib, Tiwari \& Srivastava, 2002). Since SCM involves complex systems of cross-organizational activities and processes relevant to the flow of products, services, and information, effective SCM is influenced by information technology (Barua, 2004; Forman \& Lippert, 2005; Nissen \& Sengupta, 2006; Ranganathan, Dhaliwal \& Teo, 2004; Rodriguez-Escobar \& Gonzalez-Benito, 2015).

Little research has been solely devoted to revealing characteristics of USCM and their unique relationships by taking both supply chain and ubiquitous computing aspects into account. Prior researches in supply chain management (SCM), however, have dealt with various issues including inventory management (Cohen \& Lee, 1998; Mabert \& Venkataraman, 2008), materials management (Turner, 1993), interorganizational capabilities (Ho, Au \& Newton, 2002), SCM framework (Gunasekaran \& Ngai, 2005; Sabbaghi \& Vaidyanathan, 2008), SCM strategy (Vickery et al. 2003), SCM effect (Corsten \& Gruen, 2003; Morberg et al., 2004; Subramani, 2004), SCM development (Rajib, Tiwar \& Srivastava, 2002), IT application in SCM (Barua, Konana, Whinston, 2004; Nissen \& Sengupta, 2006), various types of SCM based on its key dimensions (Cecere, 2006) and interrelations among key factors of power, benefits and risk reduction to the performance of the supply chain (Zelbst et al., 2009).

Ubiquitous computing technologies are offering firms a new opportunity in terms of supply chain management within and across companies, and integrating a number of organizational, functional, and technological issues (Hackenbroich et al., 2006, Schapranow et al., 2012). As ubiquitous computing becomes more mobile and pervasive, ubiquitous supply chain management (USCM) has emerged as a key issue for organizations pursuing supply chain transaction processing accurately, quickly and efficiently. In this research, USCM is defined as the planning, control, and management of the supply chain based on ubiquitous computing technologies such as RFID, sensors, mobile devices, PDAs, global positioning system and so on. USCM encompasses a range of activities, such as purchasing, materials handling, production planning and control, warehousing, logistics, inventory management, distribution, delivery and vendor management (Fish \& Forrest, 2006; Ranganathan et al., 2004).

In addition, the review of those studies from two aspects directs a useful background to the present research. Firstly, from the management perspective, Fish and Forrest (2006) reported seven factors underlying successful RFID adoptions and the reasons for launching RFID implementations, based on their consulting experience to RFID adoption 


\section{Issues in Information Systems \\ Volume 17, Issue I, pp. 1-13, 2016}

companies. The seven impact factors are as follows: (1) develop a clear strategy with top management support; (2) implement RFID as a project; (3) manage a gradual rollout: 'start small, dream big'; (4) continually improve procedures; (5) work on negotiation and build trust among flexible partners; (6) utilize a cross-functional team; and (7) fully develop the technology throughout the whole supply chain. Although these seven factors are not verified with empirical data, it provides a theoretical base in selecting appropriate major variables for successful USCM adoption. Moreover, Kourouthanassis and Roussos (Kourouthanassis \& Roussos, 2006) addressed the design of pervasive retail experiences brought about by the emergence of ubiquitous computing. They argued that the most important issues deriving from the development of ubiquitous retail applications are trust and privacy. This study showed the practical application of ubiquitous computing to a pervasive retail business. Recently Schapranow et al. (2012) proposed RFIDbased pharmaceutical architecture and compared operative factors of an on-premise and an on-demand solution from the management perspective. It showed the significance of both management and technical perspectives for an adoption of USCM in extending our insights.

Secondly, from a technical perspective, Roussos (2006) addressed the supply chain management standards for ubiquitous commerce. He reviewed first the history of unique identifiers and product classification systems, and then an overview of the European Article Numbering-Uniform Code Council (EAN.UCC) system, including its recent specifications for the wireless auto-identification of products. Finally, global cataloging schemes and standards for ubiquitous commerce are examined. Since this article tends to focus on the review of supply chain management standards, it would contribute to further research on the emerging standards for USCM. Hackenbroich et al. (2006) described enterprise software for supply chain management, focusing on SAP's SCM and automatic identification (Auto-ID) technology, discussing two Auto-ID pilot cases. As both RFID and Auto-ID are major technologies in USCM adoption, it would appear a good example for the better understanding of a relationship between ubiquitous technologies and U-business applications. Thiesse et al. (2006) described the design and adoption of a real-time identification and localization system using RFID and ultrasound sensor technologies to improve tracking visibility for inbound logistics. This article is reliable for extending our view of the RFID and ubiquitous technology applications in ubiquitous computing. Table 1 summarizes previous researches of critical impact factors between USCM and SCM, and they are arranged together for comparison.

Table 1. Prior Researches on Comparing CSFs Between USCM and SCM

\begin{tabular}{|c|c|c|c|c|}
\hline \multirow{2}{*}{ Factors } & \multicolumn{2}{|l|}{ USCM } & \multicolumn{2}{|c|}{ SCM } \\
\hline & CSF & Reference & $\mathrm{CSF}$ & Reference \\
\hline $\begin{array}{l}\text { Managerial } \\
\text { Factors }\end{array}$ & $\begin{array}{l}\text { Top management strong support } \\
\text { CEO's cooperative relationship with CIO } \\
\text { Continuous investment in the new IT } \\
\text { Providing valuable information on supply chain for } \\
\text { a supplier } \\
\text { Creating a new source of profit } \\
\text { Development of a new ubiquitous-oriented supply } \\
\text { chain model } \\
\text { Innovative ideas of the management board } \\
\text { Firms' progressive image change } \\
\text { Standardization of business and process } \\
\text { Right view of the top management for the USCM } \\
\text { adoption } \\
\text { Conducting business process reengineering } \\
\text { Process design based on the portability of } \\
\text { ubiquitous computing } \\
\text { Adventurous spirit ventured into an unaccustomed } \\
\text { area } \\
\text { User-oriented USCM development } \\
\text { Develop a USCM strategy planning } \\
\text { Work on negotiation and build trust among flexible } \\
\text { partners } \\
\text { Organization of a cross-functional project team } \\
\text { Cultural change management } \\
\text { End-to-end process management } \\
\text { Cross-functional USCM planning } \\
\text { Risk management for USCM } \\
\text { Organizational knowledge intensity for USCM } \\
\text { Working experience of project participator in } \\
\text { supply chain } \\
\text { Understanding parent-child relationship between } \\
\text { suppliers } \\
\text { Long-term relationship with suppliers } \\
\text { Planning for long-term supply chain improvement } \\
\text { Supplier performance management }\end{array}$ & $\begin{array}{l}\text { Crone (2006) } \\
(2006) \\
\text { Fish \& Forrest (2006) } \\
\text { Finley \& Srikanth (2005) } \\
\text { Gattorna (2006) } \\
\text { Kourouthanassis \& Roussos } \\
\text { (2003) } \\
\text { IDTechEx (2005a) } \\
\text { IDTechEx (2005b) } \\
\text { KIDL (2006) } \\
\text { Kim et al. 2008) } \\
\text { Lee \& Kim (2003) } \\
\text { Metro Group (2004) } \\
\text { Moberg et al. (2004) } \\
\text { Nomura Laboratory (2003) } \\
\text { North (2006) } \\
\text { O'Connor (2006a) } \\
\text { O'Connor (2006b) } \\
\text { O'Connor (2005) } \\
\text { O'Connor (2003) } \\
\text { Romano \& Finley } \\
\text { (2006) } \\
\text { SRI Consulting } \\
\text { (2004) } \\
\text { Tompkins et al. (2006) } \\
\text { Hsi \& Fait (2005) }\end{array}$ & $\begin{array}{l}\text { Strategic alignment } \\
\text { Unified channel } \\
\text { Contiguous participants } \\
\text { Channelwide metrics } \\
\text { Top management support } \\
\text { Training \& education } \\
\text { Long-term focus on SCM } \\
\text { Skill \& competence } \\
\text { SCM commitment } \\
\text { Supply chain planning } \\
\text { Delivery coordination } \\
\text { Culture of competitiveness and knowledge } \\
\text { development }\end{array}$ & $\begin{array}{l}\text { Gammelgaard \& Larson } \\
(2001) \\
\text { Ngai et al. (2004) } \\
\text { Moberg et al. (2004) } \\
\text { Karkkainen et al. (2007) } \\
\text { Hult et al. (2007) }\end{array}$ \\
\hline $\begin{array}{l}\text { Technical } \\
\text { Factors }\end{array}$ & $\begin{array}{l}\text { Accumulated systems development ability } \\
\text { Development of USCM in a stable system }\end{array}$ & $\begin{array}{l}\text { Carter et al. (2005) } \\
\text { Cecere (2006) }\end{array}$ & $\begin{array}{l}\text { Connectivity in quasi-real time } \\
\text { Communication }\end{array}$ & $\begin{array}{l}\text { Jeong \& Hong (2008) } \\
\text { Ngai et al. (2004) }\end{array}$ \\
\hline
\end{tabular}




\begin{tabular}{|c|c|c|c|c|}
\hline & $\begin{array}{l}\text { infrastructure } \\
\text { Pursuit of technological stability } \\
\text { Adoption of the standard client server method } \\
\text { Improved system use efficiency } \\
\text { Providing a convenient interface } \\
\text { Successful connection to the existing systems } \\
\text { Successful replacement of the existing system by } \\
\text { USCM adoption } \\
\text { Adoption of the suitable RFID technology } \\
\text { Utilizing the RFID technology widely } \\
\text { Using the standardized ubiquitous technology } \\
\text { Design and development of USCM systems with a } \\
\text { long term view } \\
\text { Development of user-friendly USCM systems } \\
\text { Implement USCM as a project } \\
\text { Gradual development of USCM : 'start small, } \\
\text { dream big” } \\
\text { Continually improve procedures of USCM } \\
\text { systems } \\
\text { Fully develop the technology throughout the whole } \\
\text { supply chain } \\
\text { Enacted view of technology adoption } \\
\text { Project participant's broad skills across multiple } \\
\text { dimensions in USCM } \\
\text { Optimal USCM network design } \\
\text { Security management of USCM systems } \\
\text { CIO as a business innovator, not simply a } \\
\text { technology manager } \\
\text { Good network infrastructure } \\
\text { Periodical evaluation of supply chain networks } \\
\text { RFID tag price } \\
\text { Standardisation for USCM } \\
\text { Supply-chain visibility } \\
\text { Interconnected supply chain network of firms } \\
\text { Industry-level databases on supplier performance } \\
\text { Inventory visibility }\end{array}$ & $\begin{array}{l}\text { Crone (2006) } \\
\text { Fish \& Forrest (2006) } \\
\text { IDTechEx (2005a) } \\
\text { IDTechEx (2005b) } \\
\text { Johnson (2006) } \\
\text { KIDL (2006) } \\
\text { Kim et al. (2008) } \\
\text { Lee \& Kim (2003) } \\
\text { Nomura Laboratory (2003) } \\
\text { Metro Group (2004) } \\
\text { Moody (2006) } \\
\text { O'Connor (2006a) } \\
\text { O'Connor (2006b) } \\
\text { O'Connor (2005) } \\
\text { O'Connor (2003) } \\
\text { Roussos (2006b) } \\
\text { SRI Consulting (2004) } \\
\text { Hsi \& Fait (2005) }\end{array}$ & $\begin{array}{l}\text { Data security } \\
\text { Hardware \& software reliability } \\
\text { Centralization of IT unit } \\
\text { IT knowledge } \\
\text { Integrated IT infrastructure } \\
\text { IT-enabled supply chain integration } \\
\text { Information intefrity } \\
\text { Operational information exchange } \\
\text { Strategic information exchange }\end{array}$ & $\begin{array}{l}\text { Ranganathan et al. (2004) } \\
\text { Nguyen \& Harrison (2004) } \\
\text { Moberg et al. (2004) } \\
\text { Rai et al. (2006) }\end{array}$ \\
\hline
\end{tabular}

As seen in Table 1, it appears that contemporary studies on USCM focus more on exploratory approaches, whereas the past researches examined it from different perspectives: either (1) management or (2) technology. The research on the technical perspective has a somewhat narrow focus and barely considers such aspects as inter-organizational relationships which are closely associated with USCM adoption. Meanwhile, the research on the management aspect is much wider in research focus but there is a limit to its explanatory power due to its lack of technical concerns. With such a background, this study stresses the significance of a unified perspective for clear investigation of the adoption of USCM by resolving the subject from two different viewpoints: management and technical aspects.

Firstly, critical success factors (CSFs) of ubiquitous supply chain management (USCM) includes more factors relevant to relationship management and new supply chain models with emerging technologies, while CSFs of SCM have more things to do with organizational level (Hult, Ketchen \& Arrfelt, 2007; Karkkainen et al., 2007). The recent SCM researches have shifted to how to take advantage of the emerging technologies into creating a new business model and innovating business processes. More precisely, CSFs of SCM in organizational level focused on optimization of a series of the value chain from suppliers to customers. Meanwhile, USCM, encompassing relationships and interactions with external alliances as well as suppliers and clients, suggests a broad and holistic paradigm changes (Rai, Patnayakuni \& Seth, 2006).

In technical aspect, secondly, researches on SCM emphasized on internal factors, such as communication, a reliability of hardware and software, and integration of IT infrastructure that can facilitate supply chain management (Nguyen \& Harris, 2004; Rai, Patnayakuni \& Seth, 2006), whereas USCM is more interested in factors of ubiquitous computing network foundation and ubiquitous technology applications. That is because USCM requires a comprehensive control of information and material flows throughout a value chain using ubiquitous technologies. It is also noted that a focus shift in technical aspect is similar to what we saw in managerial aspect. It is the shift from the optimizing efficiency of the internal supply chain process to technology applications or network infrastructure that seamlessly connect all relevant stakeholders in the value chain. These shifts together require a high level of trust among suppliers, manufacturers, distributors, and customers so that a company to strategically align itself among supply chain participants through a long-term partnership or alliance (Hult, Ketchen \& Arrfelt, 2007).

The comparison clearly depicted a departure of research foci from the prior domain. Attaining the efficiency of its own internal value chain, a company rather had an initiative on a competitive advantage over its competitors in the same 
industry. Under new converging economy, however, it is more important that a company sustain a competitive edge with 'inter-industry alliances' by effectuating communication and information flows and shortening a market response time.

Based on this review, it can be argued that further researches on USCM would be meaningful if it deals with an indepth analysis considering both management and technology issues, according to empirical data because both perspectives together may help explain and analyze the phenomenon of USCM adoption more adequately.

\section{RESEARCH METHODS}

This research attempts to find the key success factors of USCM adoption in the UK. Though there are various factors affecting USCM benefits, we cannot imagine USCM without the application of information technology. Recently, ubiquitous computing technologies have changed supply chain processes across interorganizations, increased collaboration with suppliers and customers, and improved competitiveness (Hackenbroich et al., 2006). With regards to the significance of information technology and management related to USCM adoption, we classify the key success factors into management factors and technical factors and then analyze their implications for the USCM adoption benefits.

The research procedure is as follows. First, the key success factors and benefits of USCM adoption were selected through literature review, case analysis and interviews. Second, a five-point scale survey questionnaire was developed to collect empirical data and then elaborated by interviews with academics and practical experts. Third, data collection work was carried out in the UK. Fourth, an in-depth analysis was conducted to reduce the number of success factors that are most relevant and grouped them together accordingly. Finally, the research results were summarized and major implications were addressed in the conclusion. For an empirical test, 33 items for management factors, 31 for technical factors and 27 benefit issues related to USCM adoption were measured and collected through literature review, case study and interviews with experts. According to these selected items, the survey questionnaire was developed to conduct data collection. To elaborate the survey questionnaire, the interview with academics and practical experts was executed in order to correct any obscure and unclear survey items, and to add new ones. As results of the interviews, some items were dropped and words were changed. All the survey items were contained within a five-point Likert scale. After this, a survey approach was used for collecting empirical data.

The representative analysis methods used in this study are as follows: First, the demographic characteristics of the samples are examined by applying the descriptive statistic approaches. Second, the reliability and validity of the collected data are executed to evaluate whether the survey items are reliable and the survey items are consistently valid. A factor analysis is performed for the validity analysis, and Cronbach's- $\alpha$ is used for the reliability analysis.

\section{EMPIRICAL ANALYSIS AND RESULTS}

\section{Descriptive Analysis}

The descriptive analysis of survey respondents $(\mathrm{n}=133)$ is given in Table 2, displaying industry area, a number of employees, annual turnover, function area and USCM technology adoption area. Thirty-nine were IT directors or managers and attributed to a major job position among the 133 respondents. IT and Telecommunication were the most represented industry that revealed $22 \%$ of all respondent companies. The sizes of companies were evenly distributed from less-than-50 to more-than-3000. The demographic results indicated that there was no serious bias among industries. Likewise, the study tried to include responses from various sizes of firms and functional units in the realization of USCM technology.

Table 2. Descriptive Analysis of Survey Respondents $(\mathrm{n}=133)$

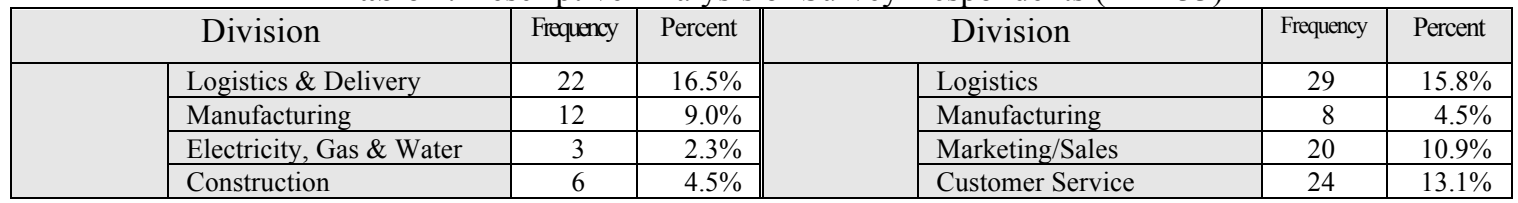




\begin{tabular}{|c|c|c|c|c|c|c|c|}
\hline \multirow{8}{*}{$\begin{array}{c}\text { Industry } \\
\text { Area }\end{array}$} & Wholesale \& Retail & 15 & $11.3 \%$ & \multirow{5}{*}{$\begin{array}{c}\text { Function } \\
\text { Area }\end{array}$} & IT/IS & 41 & $22.4 \%$ \\
\hline & Hotels \& Restaurants & 5 & $3.8 \%$ & & General Management & 35 & $19.1 \%$ \\
\hline & IT \& Telecommunication & 29 & $21.8 \%$ & & Procurement & 11 & $6.0 \%$ \\
\hline & Transport & 9 & $6.8 \%$ & & HRM & 12 & $6.6 \%$ \\
\hline & Banking \& Finance & 8 & $6.0 \%$ & & Others & 3 & $1.6 \%$ \\
\hline & Public Administration & 9 & $6.8 \%$ & \multirow{11}{*}{$\begin{array}{l}\text { USCM } \\
\text { Techn- } \\
\text { ology } \\
\text { Adoption } \\
\text { Area }\end{array}$} & Inbound Logistics & 33 & $17.7 \%$ \\
\hline & Education \& Health & 6 & $4.5 \%$ & & Production (Operations) & 21 & $11.3 \%$ \\
\hline & Social \& Personal Service & 9 & $6.8 \%$ & & Outbound Logistics & 30 & $16.1 \%$ \\
\hline \multirow{4}{*}{$\begin{array}{c}\text { Number } \\
\text { of } \\
\text { Employee }\end{array}$} & 50 or less & 39 & $29.4 \%$ & & Sales \& Marketing & 15 & $8.1 \%$ \\
\hline & $51-500$ & 32 & $24.1 \%$ & & Customer Service & 22 & $11.8 \%$ \\
\hline & $501 \sim 3000$ & 23 & $17.3 \%$ & & Administrative Infrastructure & 16 & $8.6 \%$ \\
\hline & 3001 or more & 39 & $29.3 \%$ & & Human Resources Management & 7 & $3.8 \%$ \\
\hline \multirow{4}{*}{$\begin{array}{l}\text { Annual } \\
\text { Turnover }\end{array}$} & Less than 500 thousand $£$ & 27 & $20.3 \%$ & & Technology Development & 13 & $7.0 \%$ \\
\hline & 500 thousand $\sim 25$ million & 37 & $27.8 \%$ & & Procurement & 10 & $5.4 \%$ \\
\hline & $25 \sim 200$ million $£$ & 32 & $24.1 \%$ & & Information Systems & 19 & $10.2 \%$ \\
\hline & More than 500 million $£$ & 37 & $27.8 \%$ & & Others & 0 & $0.0 \%$ \\
\hline
\end{tabular}

\section{Factor Analysis and Reliability Test}

The validity and reliability of collected data are used to judge its quality for further analysis. The purpose of the paper is to examine relationships between proposed managerial CSFs and technical CSFs, and the attainable adoption benefits of USCM. To this end, we firstly needed to draw relevant factors from ninety-one measurement items for these three constructs through exploratory factor analysis technique. We employed principle component analysis with varimax rotation as a method in factor analysis and applied the Kaiser criterion (eigenvalues $>1.0$ ) in extracting relevant factors (Tabaschnick \& Fidell, 2006).

Table 3. Results of Principle Component Analysis for Management Aspects

\begin{tabular}{|c|c|c|c|c|c|c|c|c|}
\hline Measurement Items & $\mathrm{M}$ & SD & $\begin{array}{l}\text { Eigen- } \\
\text { value }\end{array}$ & $\begin{array}{c}\% \text { of } \\
\text { variance }\end{array}$ & $\begin{array}{c}\text { Cronbach's } \\
\alpha \\
\end{array}$ & AVE & $\mathrm{CR}$ & $\begin{array}{c}\text { Factor } \\
\text { Loadings }\end{array}$ \\
\hline 1. Internal Process Management & & & 5.471 & 15.856 & .827 & .496 & .872 & \\
\hline Risk management for USCM & 3.40 & 1.11 & & & & & & .718 \\
\hline Cross functional USCM planning & 3.32 & .95 & & & & & & .709 \\
\hline Cultural change management & 3.35 & 1.08 & & & & & & 697 \\
\hline End-to-end process management & 3.70 & 1.04 & & & & & & .639 \\
\hline Trust building among business partners & 3.81 & 1.07 & & & & & & .623 \\
\hline Organizational knowledge level & 3.44 & .92 & & & & & & .621 \\
\hline Working experience & 3.47 & .92 & & & & & & .568 \\
\hline 2. Strategic Relationship Management & & & 2.196 & 14.258 & .797 & .622 & .868 & \\
\hline Planning for long-term supply chain improvement & 3.80 & .87 & & & & & & .816 \\
\hline Long-term relationship with suppliers & 3.77 & .96 & & & & & & .762 \\
\hline Strategic alignment & 3.50 & .91 & & & & & & .711 \\
\hline High level of trust & 3.86 & .93 & & & & & & 697 \\
\hline 3. Managerial Support & & & 1.497 & 8.905 & .710 & .782 & .878 & \\
\hline Top Management Support & 4.17 & .86 & & & & & & .863 \\
\hline CEO \& CIO Relationship & 3.66 & 1.08 & & & & & & .753 \\
\hline 4. Business Process Reengineering & & & 1.410 & 8.215 & .527 & .678 & .808 & \\
\hline Process design on the portability & 3.19 & .93 & & & & & & .820 \\
\hline Conduct of BPR & 3.32 & .91 & & & & & & .691 \\
\hline 5. Adaptation to Environmental Change & & & 1.305 & 7.261 & .480 & .496 & .746 & \\
\hline Supplier performance management & 3.57 & .86 & & & & & & .646 \\
\hline Entrepreneur Spirit & 3.30 & 1.06 & & & & & & .545 \\
\hline Firm's USCM environment awareness & 3.41 & 1.02 & & & & & & .538 \\
\hline
\end{tabular}




\begin{tabular}{|c|c|c|c|c|c|c|c|c|}
\hline 6. USCM Realization & & & 1.114 & 6.742 & .393 & .619 & .763 & \\
\hline Adoption of Payment Model & 3.47 & 1.10 & & & & & & .791 \\
\hline Creation of a new source of profit & 3.46 & 1.14 & & & & & & .575 \\
\hline 7. Relationship with Current Suppliers & & & 1.046 & 5.654 & N/A & $\mathrm{N} / \mathrm{A}$ & N/A & \\
\hline Strong cooperation & 3.81 & 2.73 & & & & & & .772 \\
\hline
\end{tabular}

Table 3 summarizes the anatomy of construct validity for the all of the key success factors in management aspects. Adequacy of the sample used for PCA was measured by Kaiser-Meyer-Olkin index (KMO) and Bartlett's sphericity tests whether the correlation matrix is an identity matrix. For management factors, KMO $(0.743)$ showed the adequate fit of data for factor analysis and Bartlett's test of sphericity $(\lambda 2=932.10$, d.f. $=190, p<=0.0001)$, suggesting the correlation matrix was not an identity matrix so that it could be good to proceed to further analysis. After removing variables cross-loaded, we were able to obtain seven key success factors comprising twenty-one measurement items for management aspects that have higher construct validity as shown in Table 3. All factor loadings are above .5 and, combined together, account for $66.85 \%$ of total variance. The measurement items and their construct naming are summarized in Table 3.

Through similar validation process with twenty-four technical aspects items, we extracted six key success factors as presented in Table 5. Factor analysis was also suitable for the factor extraction in technical aspects as suggested by $\mathrm{KMO}=0.82$ and Bartlett's sphericity test $(\lambda 2=1672.44$, d.f. $=325$, significance $=0.000)$. All factors provide strong construct validity, as all factor loadings were above 0.5 and the explanatory power of the factors has exceeded $63 \%$. More detailed explanations on the seven categorized factors are shown in Table 4.

Table 4. Results of Principle Component Analysis for Technical Aspects

\begin{tabular}{|c|c|c|c|c|c|c|c|c|}
\hline \multirow[b]{2}{*}{ Measurement Items } & \multicolumn{8}{|c|}{ Component } \\
\hline & M & SD & $\begin{array}{l}\text { Eigen- } \\
\text { value }\end{array}$ & $\begin{array}{c}\% \text { of } \\
\text { variance }\end{array}$ & $\begin{array}{c}\text { Cronbach's } \\
\alpha \\
\end{array}$ & AVE & $\mathrm{CR}$ & $\begin{array}{l}\text { Factor } \\
\text { loadings }\end{array}$ \\
\hline 1.USCM Technology Application & & & 8.570 & 16.661 & .852 & .532 & .888 & \\
\hline Utilization of the RFID technology & 3.20 & 1.10 & & & & & & 0.792 \\
\hline Adoption of the suitable RFID technology & 3.31 & 1.03 & & & & & & 0.772 \\
\hline Project participant's broad skill & 3.29 & .96 & & & & & & 0.660 \\
\hline Adoption of the standardized ubiquitous technology & 3.38 & .97 & & & & & & 0.637 \\
\hline Enacted view of technology adoption & 3.15 & .86 & & & & & & 0.615 \\
\hline Selection of the best outsourcing provider & 3.19 & .95 & & & & & & 0.608 \\
\hline Ubiquitous technology price & 3.41 & .94 & & & & & & 0.535 \\
\hline 2. USCM System Design & & & 2.466 & 11.735 & .814 & .477 & .864 & \\
\hline USCM design with a long term view & 3.77 & .86 & & & & & & 0.702 \\
\hline User friendly USCM adoption & 3.80 & .93 & & & & & & 0.664 \\
\hline Consideration of customer information & 3.65 & 1.04 & & & & & & 0.630 \\
\hline Continual improvement of USCM & 3.79 & .80 & & & & & & 0.595 \\
\hline $\begin{array}{l}\text { Full development of the technology throughout the } \\
\text { whole SCM }\end{array}$ & 3.73 & .83 & & & & & & 0.570 \\
\hline USCM adoption as a project & 3.55 & .76 & & & & & & 0.558 \\
\hline Security management of USCM & 3.72 & .91 & & & & & & 0.550 \\
\hline 3. USCM Network Foundation & & & 1.607 & 10.729 & .739 & .662 & .854 & \\
\hline Industry-level databases on supplier performance & 3.32 & 1.06 & & & & & & 0.689 \\
\hline Inventory visibility & 3.60 & 1.13 & & & & & & 0.608 \\
\hline Interconnected supply chain network of firms & 3.31 & 1.03 & & & & & & 0.607 \\
\hline 4. Compatibility with Existing Systems & & & 1.435 & 8.462 & .735 & .654 & .849 & \\
\hline Successful connection to the existing systems & 3.94 & 1.00 & & & & & & 0.745 \\
\hline Successful replacement of the existing system & 3.74 & .97 & & & & & & 0.623 \\
\hline Standardization for USCM & 3.51 & 1.00 & & & & & & 0.535 \\
\hline
\end{tabular}




\begin{tabular}{|c|c|c|c|c|c|c|c|c|}
\hline 5. Efficient Use of USCM & & & 1.250 & 7.992 & .716 & .641 & .842 & \\
\hline System use efficiency & 3.52 & .90 & & & & & & 0.706 \\
\hline Adoption of the standard client server method & 3.18 & 1.02 & & & & & & 0.679 \\
\hline Technological stability & 3.65 & .91 & & & & & & 0.631 \\
\hline 6. USCM Sustainability & & & 1.102 & 7.609 & .567 & .537 & .777 & \\
\hline $\mathrm{CIO}$ as a business innovator & 3.52 & 1.03 & & & & & & 0.722 \\
\hline Gradual development of USCM & 3.33 & .94 & & & & & & 0.661 \\
\hline Periodical evaluation of supply chain networks & 3.57 & .84 & & & & & & 0.512 \\
\hline
\end{tabular}

Finally, the construct validity test on USCM adoption benefits was carried out for all of the measurement items in the same manner. Both KMO (0.843) and Bartlett's sphericity $\left(\lambda^{2}=1192.37\right.$, d.f. $\left.=171, p<=0.0001\right)$ were meritorious to the adequacy of factor analysis for the adoption benefit construct. The suggested five factors, measured by nineteen items showed strong evidence of construct validity, with a factor loading well above 0.5 and with an explained variance of over $67 \%$. Table 5 provides more detailed explanations on the five categorized factors are as follows.

Table 5. Results of Principle Component Analysis for Perceived Adoption Benefits of USCM

\begin{tabular}{|c|c|c|c|c|c|c|c|c|}
\hline & \multicolumn{8}{|c|}{ Component } \\
\hline & M & SD & $\begin{array}{l}\text { Eigen- } \\
\text { value }\end{array}$ & $\begin{array}{c}\% \text { of } \\
\text { variance }\end{array}$ & $\begin{array}{c}\text { Cronbach's } \\
\alpha \\
\end{array}$ & AVE & $\mathrm{CR}$ & $\begin{array}{c}\begin{array}{c}\text { Factor } \\
\text { loadings }\end{array} \\
\end{array}$ \\
\hline 1. Cost Savings & & & 7.055 & 21.132 & .887 & .564 & .911 & \\
\hline Cost savings & 3.57 & 1.07 & & & & & & 0.775 \\
\hline Against business counterfeiting or theft & 3.38 & 1.15 & & & & & & 0.765 \\
\hline Eliminate packing and shipping errors & 3.47 & 1.22 & & & & & & 0.761 \\
\hline Eliminate excess inventory & 3.46 & 1.04 & & & & & & 0.707 \\
\hline Reduce stock-outs & 3.38 & 1.15 & & & & & & 0.593 \\
\hline Reduce procurement costs & 3.61 & 1.11 & & & & & & 0.584 \\
\hline Establish real-time supply chain intelligence & 3.63 & .85 & & & & & & 0.567 \\
\hline Reduce logistics cost & 3.66 & 1.05 & & & & & & 0.565 \\
\hline 2. Creation of Competitive Edge & & & 1.729 & 14.636 & .801 & .557 & .862 & \\
\hline Create new market opportunities & 3.51 & .98 & & & & & & 0.761 \\
\hline Enhance customer responsiveness & 3.84 & .92 & & & & & & 0.728 \\
\hline Improve the organization conduct business & 3.85 & .93 & & & & & & 0.692 \\
\hline Enhance employee productivity & 3.86 & .81 & & & & & & 0.641 \\
\hline Improve data collection accuracy & 3.86 & .87 & & & & & & 0.581 \\
\hline 3. Process Efficiency & & & 1.591 & 10.813 & .708 & .774 & .873 & \\
\hline Save money & 3.51 & 1.21 & & & & & & 0.811 \\
\hline Eliminate a lot of the manual intervention & 3.89 & .97 & & & & & & 0.789 \\
\hline 4. Facilitating Partnership & & & 1.302 & 10.605 & .620 & .722 & .838 & \\
\hline Improve supplier relationships & 3.87 & .96 & & & & & & 0.745 \\
\hline Better response to partners & 3.72 & .93 & & & & & & 0.678 \\
\hline 5. Improvement in Inventory Control & & & 1.084 & 9.974 & .713 & .727 & .842 & \\
\hline Enable track and trace authentication & 3.80 & 1.01 & & & & & & 0.745 \\
\hline Improve supply-chain visibility & 3.78 & .96 & & & & & & 0.743 \\
\hline
\end{tabular}

After having the construct validity observed, all items were collectively tested for the reliability. The reliability of each group factors is determined by Cronbach's $\alpha$ and composite reliability (CR). As seen in Table 3, 4 and 5, this study also reported CR and average variance extracted (AVE) for more concrete reliability result. The threshold value for CR is greater than 0.7 (Fornell \& Larker, 1981) or even 0.6 acceptable (Bagozzi \& Yi, 1988). Fornell and Larcker (1981) suggested AVE above 0.5 is a good indication of convergent validity. As appeared in the Tables, all 


\section{Issues in Information Systems \\ Volume 17, Issue I, pp. 1-13, 2016}

extracted factors for management aspects, technical aspects, and adoption benefits meet this requirement suggesting adequacy of utilizing all of these factors for further analysis.

\section{DISCUSSIONS AND CONCLUSION}

The objective of this paper is to identify the key success factors of ubiquitous supply chain management (USCM) adoption. This study elaborated to extract these factors in the relationships among management aspects, technology aspects, and USCM adoption benefits by examining the holistic relations among those latent constructs. To this end, the study employed principle component analysis to extract most relevant factors from the pool of candidate factors that are previously proposed. In this sense, this paper contributes to the literature in two-folds: (1) by empirically providing key impact factors of USCM from two different perspectives, and (2) suggesting a possible interrelation among the predictor variables and enhancing the views of the development of a USCM adoption model.

It successful reduced the number of relevant factors and grouped them into two causal constructs to USCM benefit construct. There are seven success factors were extracted for managerial construct and they are Internal Process Management, Strategic Relationship Management, Managerial Support, Business Process Reengineering, Adaptation to Environmental Change, USCM Realization, and Relationship with Current Suppliers. In addition, six factors were identified for technology construct. They are USCM Technology Application, USCM System Design, USCM Network Foundation, Compatibility with Existing Systems, Efficient Use of USCM, and USCM Sustainability.

Moreover, the USCM adoption model formulates these two constructs with perceived benefits quantified by Cost Savings, Creation of Competitive Edge, Process Efficiency, Facilitating Partnership, and Improving Inventory Control. It appears that both the management factors and the technical factors are significantly associated with USCM adoption and may make potential antecedent relationships between managerial and technical factors to the adoption benefits in contemporary UK USCM circumstances. Conclusively, it is argued that the adoption of USCM in the UK can be seen as a shaping process facilitated by both management factors and technical issues in a current ubiquitous computing environment. In addition, one can take the position that the UK enterprise tends to adopt USCM to reap the benefits of cost saving as a short term gain, achieving competitive advantage, facilitating partnership with suppliers and improving its inventory management as long-term leverage.

Since ubiquitous computing technology is increasingly applied to the supply chain management, the critical success factors and their structural scheme proposed by this research is useful for both researchers and practitioners because it is a framework that illustrates the current nature of the issues that are in a chaotic state. The theoretical and practical findings addressed in this research have given new insights for future researches. For practitioners, the present study reviewed previous literatures about impact factors in SCM and pinned down several relevant factors in the context of ubiquitous SCM environment, which helps decision makers prioritize areas of the investment in implementing USCM depending on their short- or long-term objectives. For academia, the findings of this research suggest possible procuring effects of technological factors toward managerial factors and in turn, lead to the adoption benefit. This insight casts rooms for future research to delve into more accurate relationships among those measurement factors. As an extension of this study, hence it would be worthwhile to attempt to apply the USCM adoption model and revalidate them within a broader USCM and ubiquitous computing research context.

\section{REFERENCES}

Andriolo, A., Battini, D., Calzavara, M., Gamberi, M., Peretti, U., Persona, A., Pilati, F., \& Sgarbossa, F. (2016). New RFID pick-to-light system: Operating characteristics and future potential. International Journal of RF Technologies, 7(1), 43-63.

Bagozzi, R.P. \& Yi, Y. (1988). On the evaluation of structural equation models. Academic of Marketing Science, (16)1, 76-94.

Barua, A., Konana, P., Whinston, A. \& Yin, F. (2004). An empirical investigation of net-enabled business value. MIS Quarterly, 28(4), 585-620. 
Caputo, A.C., Cucchiella, F., Fratocchi, L., Pelagagge, P.M. \& Scacchia, F. (2004). Analysis and evaluation of esupply chain performances. Industrial Management \& Data Systems, 104(7), 546-567.

Carter, P.J., Monczka, R.M. \& Mosconi, T. (2005). Looking at the future of supply measurement. Supply Chain Management Review, 9(9), 27-29.

Cecere, L. (2006). A changing technology landscape. Supply Chain Management Review, 10(1), 15-16.

Cohen, M. \& Lee, H.L. (1998). Strategic analysis of integrated production-distribution systems: models and methods. Operations Research, 36(2), 216-228.

Corsten D. and Gruen T.W. (2003). Desperately seeking shelf availability: an examination of the extent, the causes, and the efforts to address retail out-of-stocks, International Journal of Retail \& Distribution Management, $31(12), 605-617$.

Corsten, D. \& Kumar, N. (2005). Do suppliers benefit from collaborative relationships with large retailers? An empirical investigation of efficient consumer response adoption. Journal of Marketing, 69(3), 80-94.

Crone, M. (2006). Are global supply chains too risky? A practitioner's perspective, Supply Chain Management Review, $10(4), 28-35$.

Dos Santos, B.L. \& Smith, L.S. (2008). RFID in the Supply Chain: Panacea or Pandora's Box? Communications of the $A C M, 51(10), 127-131$.

Findley, F. \& Srikanth, S. (2005). Imperatives for successful collaboration. Supply Chain Management Review, 9(1), 30-37.

Fish, L. \& Forrest, W. (2006). The 7 success factors of RFID. Supply Chain Management Review, 10(6), 26-32.

Fornell, C. \& Larker, D.F. (1981). Evaluating structural equation models with unobservable variables and measurement error. Journal of Marketing Research, 18(1), 39-50.

Forman, H. \& Lippert, S. (2005). Toward the development of an integrated model of technology internalization within the supply chain context. The International Journal of Logistics Management, 16(1), 4-27.

Gammelgaard, B. and Larson, P. (2001). Logistics Skills and Competencies for Supply Chain Management. Journal of Buisness Logistics, 22(2), 27-50.

Gattorna, J. (2006). Living Supply Chains: how to mobilize the enterprise around delivering what your customers want, London, UK: Prentice Hall.

Giner, P., Cetina, C., Fons, J. \& Pelechano, V. (2011). Implicit interaction design for pervasive workflows. Personal \& Ubiquitous Computing, 15(4), 399-408.

Gunasekaran, A. \& Ngai, E.W.T. (2005). Build-to-order supply chain management: a literature review and framework for development. Journal of Operations Management, 23(5), 423-451.

Hackenbroich, G., Bornhovd, C., Haller, S. \& Schaper, J. (2006). Optimizing Business Process by Automatic Data Acquisition: RFID Technology and Beyond, in Roussos, G., (Ed.) Optimizing Business Process by Automatic Data Acquisition: RFID Technology and Beyond, London, UK: Springer, 33-51.

Hickey, K. (2004, March). Targeting the tagging bandwagon. Traffic World, 12-13. 
Ho, D.C.K., Au, K.F. \& Newton, E. (2002). Empirical research on supply chain management: a critical review and recommendations. International Journal of Production Research, 10(17), 4425-4430.

Hou, J., \& Huang, C. (2006). Quantitative performance evaluation of RFID applications in the supply chain of the printing industry. Industrial Management \& Data Systems, 106(1), 96-120.

Hult, G. T., Ketchen, D. J. and Arrfelt, M. (2007). Strategic Supply Chain Management: Improving Performance through a Culture of Competitiveness and Knowledge Development. Strategic Management Journal, 28, 1035-1052.

Hsi, S. \& Fait, H. (2005). RFID Enhances Visitors' museum experience at the Exploratorium. Communications of the $A C M, 48(9), 60-65$.

Hsieh, C.T. \& Lin, B. (2004). Impact of standardization on EDI in B2B development. Industrial Management \& Data Systems, 104(4), 68-77.

Hult, G.T., Ketchen, D.J. \& Arrfelt, M. (2007). Strategic supply chain management: Improving performance through a culture of competitiveness and knowledge development. Strategic Management Journal, 28(10), 1035-1052.

IDTechEx. (2005a). An Introduction to RFID and Tagging Technologies. Retrieved from http://www.idtechex.com.

IDTechEx. (2005b). RFID Forecasts, Players and Opportunities 2005 to 2015. Retrieved from http://www.idtechex.com

Jeong, J. S. and Hong, P. (2007). Customer Orientation and Performance Outcomes in Supply Chain Management. Journal of Enterprise Information Management, 20(5), 578-594.

Johnson, M.E. (2006). Ready for the digital future? Supply Chain Management Review, 10(4), 26-32.

Karkkainen, M., Laukkanen, S., Sarpola, S. \& Kemppainen, K. (2007). Roles of interfirm information system in supply chain management. International Journal of Physical Distribution \& Logistics Management, 37(4), 264-286.

Kourouthanassis, P. \& Roussos, G. (2006). The design of pervasive retail experiences, in Roussos, G., (Ed.) The Design of Pervasive Retail Experiences, London, UK: Springer.

Lee, J.N. \& Kim, Y.G. (2003). Exploring a Causal Model for the Understanding of Outsourcing Partnership, Proceedings of the $36^{\text {th }}$ Hawaii International Conference on System Sciences, Washington D.C: IEEE Computer Society, 268-277.

Lopez, T.S., Ranasinghe, D.C., Harrison, M., McFarlane, D. (2012). Adding sense to the Internet of things, Personal and Ubiquitous Computing, 16(3), 291-308.

Mabert, V.A. \& Venkataraman, M.A. (2008). Special research focus on supply chain linkages: Challenges for design and management in the 21st century, Decision Sciences, 29(3), 537-552.

Metro Group (2004). Annual Report The spirit of commerce. Retrieved from http://www.metrogroup.de/internet/site/metrogroup/get/documents/metrogroup_international/corpsite/80_glob al/publications/AR2004-en.pdf

Moberg, C.R., Whipple, T.W., Cutler, B.D. and Speh, T.W. (2004). Do the management components of supply chain management affect logistics performance? The International Journal of Logistics Management, 15(2), 15-30.

Moody, P. (2006). With supply management, technology rules. Supply Chain Management Review, 10(3), 41-48. 
Narayanaswami, C., Kruger, A. \& Marmasse, N. (2011). Pervasive retail, IEEE Pervasive Computing, 10(2), 16-18.

Ngai, E. W. T., Cheng, T. C. E. and Ho, S. S. M. (2004). Critical Success Factors of Web-Based Supply-Chain Management Systems: an Exploratory Study. Production Planning \& Control, 15(6), 622-630.

Nguyen, H.M. \& Harrison, N.J. (2004). Electronic supply-chain orientation and its competitive dimensions, Production Planning and Control, 15(6), 596-607.

Niederman, F.A. \& Mathieu, R.G. (2006). Examining RFID application in supply chain management. Communications of the $A C M, 50(7), 92-101$.

Nissen, M. \& Sengupta, K. (2006). Incorporating software agents into supply chains: experimental investigation with a procurement task. MIS Quarterly, 30(1), 145-166.

Nomura Laboratory (2003). Ubiquitous network and new society systems. Electronic Times News. Retrieved from http://english.etnews.co.kr.

North, M. (2006). Supplier performance management can make a difference. Supply Chain Management Review, 10(7), $13-15$.

O'Connor, M.C. (2003). Airline Interest in RFID on the Rise, RFID Journal. Retrieved from http://www.rfidjournal.com/article/articleprint/502/-1/1/

O'Conner, M.C. (2005), Efficiencies drive RFID adoption. RFID Journal. Retrieved from http://rfidjournal.com/article/articleview/1883/1/1

O’Connor, M.C. (2006a), Kimberly-Clark getting RFID Gen2 ready, RFID Journal. Retrieved from www.rfidjournal.com/article/articleprint/2161/-1/1

O'Connor, M. C. (2006b). TI, Smurfit-Stone Demo RFID-Enabled Cases, RFID Journal.

Rai, A. Patnayakuni, R. \& Seth, N. (2006). Firm performance impacts of digitally enabled supply chain integration capabilities. MIS Quarterly, 30(2), 225-246.

Rajib, P., Tiwari, D. \& Srivastava, G. (2002). Design and development of an integrated supply chain management system in an internet environment. Journal of Services Research, 2(1), 75-93.

Ranganathan, C. Dhaliwal, J.S. \& Teo, T.S.H. (2004). Assimilation and diffusion of web technologies in supply-chain management: an examination of key drivers and performance impacts. International Journal of Electronic Commerce, 9(1), 127-161.

Rodriguez-Escobar, J.A. \& Gonzalez-Benito, J. (2015). The role of information technology in purchasing function. Journal of Business \& Industrial Marketing, 30(5), 498-510.

Romano, A.M. \& Finley, F. (2006). How Ann Taylor put strategic sourcing on the management. Supply Chain Management Review, 10(7), 32-40.

Roussos, G., (2006). Supply chain management standards in ubiquitous commerce, in Roussos, G., (Ed.). Supply Chain Management Standards in Ubiquitous Commerce, London, UK: Springer, 15-31.

Sabbaghi, A. \& Vaidyanathan, G. (2008). Effectiveness and efficiency of RFID technology in supply chain management: strategic values and challenges. Journal of Theoretical and Applied Electronic Commerce Research, 3(2), 71-81. 
Schapranow, M-P., Müller, J., Zeier, A. \& Plattner, H. (2012). Costs of authentic pharmaceuticals: research on qualitative and quantitative aspects of enabling anti-counterfeiting in RFID-aided supply chains. Journal of Personal and Ubiquitous Computing, 16(3), 271-289.

Spekman, R.E., \& Sweeney, P.J. (2006). RFID: From concept to implementation. International Journal of Physical Distribution \& Logistics Management, 36(10), 736-754.

SRI Consulting. (2004). RFID Technologies, SRI Consulting Business Intelligence. Retrieved from http://www.strategicbusinessinsights.com/explorer/RFID/RFID.2004-03.shtml

Subramani, M. (2004). How do suppliers benefit from information technology use in supply chain relationships? MIS Quarterly, 28(1), 45-73.

Tabaschnick, B.G. \& Fidell, L.S. (2006). Using Multivariate Statistics, Boston, MA: Allyn \& Bacon.

Thiesse, F., Fleisch, E. \& Dierkes, M. (2006). LotTrack: RFID-based process control in the semiconductor industry. IEEE Pervasive Computing, 5(1), 47-53.

Tompkins, J.A., Simonson, S.W., Tompkins, B.W. \& Upchurch, B.E. (2006). Relationships: the key to outsourcing success. Supply Chain Management Review, 10(5), 13-18.

Trappey, A.J.C., Trappey, C.V., Hou, J.L. \& Chen, B.J.G. (2004). Mobile agent technology and application for online global logistic services. Industrial Management \& Data Systems, 104(2), 169-183.

Turner, J. R. (1993). Integrated supply-chain management: what's wrong with this picture? Industrial Engineering, 25(12), 523-539.

Vickery, S.K., Jayaram, J., Droge, C. \& Calantone, R. (2003). The effects of an integrative supply chain strategy on customer service and financial performance: An analysis of direct versus indirect relationships. Journal of Operation Management, 21(5), 523-539.

Ward, D.M. (2004, August 26). 5-Cent tag unlikely in 4 years. RFID Journal. Retrieved from http://www.rfidjournal.com/article/articleview/1098/1/1.

Wicks, A.M., Visich, J.K., \& Li, S. (2006). Radio frequency identification applications in healthcare. International Journal of Healthcare Technology and Management, 7(6), 522-540.

Wu, W.Y., Chiag, C.Y., Wu, Y.J. \& Tu, H. J. (2004). The influencing factors of commitment and business integration on supply chain management. Industrial Management \& Data Systems, 104(4), 322-333.

Zelbst, P.J., Jr., Green, K.W., Sower, V.E. \& Reyes, P. (2009). Impact of supply chain linkages on supply chain performance. Industrial Management \& Data Systems, 109(5), 665-682. 